\title{
Quantitative Analysis Ageing Status of Natural Ester-paper Insulation and Mineral Oil-paper Insulation by Polarization/Depolarization Current
}

\author{
Jian Hao', Ruijin Liao', George Chen ${ }^{2}$, Zhiqin Ma ${ }^{1}$ and LijunYang ${ }^{1}$ \\ ${ }^{1}$ State Key Laboratory of Power Transmission Equipment \& System Security and New Technology \\ Chongqing University, Shapingba District, Chongqing 400044, China \\ ${ }^{2}$ School of Electronics and Computer Science \\ University of Southampton, Southampton SO17 1BJ, UK
}

\begin{abstract}
Polarization and Depolarization Current (PDC) technique is an effective tool to assess the condition of oil-paper insulation system in power transformers. So far the PDC behaviors of mineral oil-paper insulation have been widely investigated. However, with the increasing number of transformer choosing natural ester as its insulation oil, it is important to investigate the PDC characteristics of natural ester-paper insulation to see whether the PDC technique can also be used to assess the condition of new insulation system using natural ester in transformers accurately. In this research, natural esterpaper insulation sample and mineral oil-paper insulation sample were subjected to thermally accelerated ageing experiment at $110{ }^{\circ} \mathrm{C}$ for 120 days. The PDC characteristics of natural ester-paper insulation sample and mineral oil-paper insulation sample were compared over the ageing process. A new method for assessing the ageing condition of the oil-paper insulation in terms of the depolarization charge quantity was proposed. Results show that the polarization/depolarization current of natural ester-paper insulation sample is higher than that of mineral oil-paper insulation sample with the same ageing intervals. The depolarization charge quantity of both kinds of oil-paper insulation sample is very sensitive to their ageing conditions. There is an exponential relation between the stable depolarization charge quantity of both kinds of oil-paper insulation sample and the degree of polymerization (DP) of paper. The depolarization charge quantity can be used to predict the ageing condition of oil-paper insulation providing the measurement temperature is kept the same.
\end{abstract}

Index Terms - Natural ester, mineral oil, oil-paper insulation, power transformer, polarization/depolarization current, depolarization charge quantity, ageing condition.

\section{INTRODUCTION}

POWER transformers play a vital role in the whole electrical power system. The main insulation system of power transformer consists of cellulosic material and insulation oil, which degrades under a combined action of thermal, electrical, mechanical and chemical stresses during transformer routine operation [1-2]. The degradation of the main insulation system in transformer is recognized to be one of the major causes of transformer breakdown [3-7]. Therefore, accurately assessing the status of the transformer insulation is essential and important.

In recent years, the need to assess the insulation system nondestructively and reliably has driven the development of dielectric response diagnostic tools, which are based on the changes in the dielectric properties of the oil-paper insulation

Manuscript received on 28 May 2011, in final form 18 September 2011.
[7-10]. Polarization/depolarization current (PDC) is not only a non-destructive dielectric method being widely used to assess the moisture content and ageing condition of mineral oil-paper insulation used in transformers, but also a diagnostic method which has attracted attention of a large number of scholars and engineers in recent years. There are many reports about the influence of moisture, ageing and testing temperature on the PDC characteristics of mineral oil-paper insulation [7, 11-15], because a combination of mineral oil with cellulose materials is widely used as the main insulation system in transformers. However, at the moment there is no report about how to use PDC to assess the ageing condition of the oil-paper insulation.

In the new century, the performance of the mineral oil starts to be limited due to environmental consideration [16-19]. Therefore, nowadays a special focus has been carried out on new alternative insulation liquids for mineral oil [16-19]. Natural esters offer fire safety, environment and insulation 
ageing advantages over mineral oil, and are found to be suitable for use in transformer insulation system [16-19]. There are two typical commercial products of natural ester named BIOTEMP and FR3, which have currently been used in small power and distribution transformers, and further improvements are ongoing in the hope that they would be widely applied in large power transformers. However, reports about the PDC behavior of natural ester-paper insulation are very limited though the number of transformer choosing natural ester as its insulation oil is increasing. Muhamad et al [20] compared the polarization/depolarization current behavior of natural ester and mineral oil with different moisture levels. They concluded that the trends of the PDC response were different for the two insulation oils and the PDC technique provides significant information that can be used in the evaluation of the transformer condition.

The degradation of the cellulosic materials immersed in insulation oil determines the remaining life of transformer [12]. To fully utilize the PDC technique to assess the ageing condition of oil/paper insulation system using natural ester and mineral oil, the following questions are required to be answered. What's the PDC difference between natural esterpaper insulation and mineral oil-paper insulation? If the PDC technique in diagnostics of insulation system used mineral oil is suitable for making diagnosis of natural ester-paper insulation, and how to make quantitative analysis of ageing status of natural ester-paper insulation and mineral oil-paper insulation by the PDC method? Detailed study on the PDC characteristics of natural ester-paper insulation and mineral oil-paper insulation under different ageing conditions is helpful to resolve questions above.

In this paper, a comparative result of the influence of ageing on the PDC characteristics of natural ester-paper insulation and mineral oil-paper insulation is provided. Modeling PDC data with $\mathrm{R}-\mathrm{C}$ circuit parameters is one of the most common techniques utilized in insulation condition assessment [21-23]. The R-C circuit parameters of natural ester-paper insulation sample and mineral oil-paper insulation sample with different ageing conditions are fitted by their depolarization current. And then the depolarization charge quantity changing with the ageing condition of the oil-paper insulation samples is analyzed. At last, a new method for quantitative analysis ageing status of natural ester-paper insulation and mineral oilpaper insulation by PDC method is proposed.

\section{PDC PRINCIPLE THEORY}

The measurement of the polarization and depolarization currents following a dc voltage step is one way in the time domain to investigate the slow polarization processes of dielectrics [7-15]. When an electric field which is generated by an external voltage $u(t)$ is applied on the dielectric material, the current through the dielectric material can be expressed as:

$$
i(t)=C_{0}\left[\frac{\sigma}{\varepsilon_{0}} u(t)+\varepsilon_{r} \frac{d u(t)}{d t}+\frac{d}{d t} \int_{0}^{t} f(t-\tau) u(\tau) d \tau\right]
$$

where,

$C_{0}$ : geometrical capacitance of the dielectric material, $u(t)$ : the step voltage,

$\sigma:$ the dc conductivity of the dielectric material, $\varepsilon_{0}: 8.852 * 10^{-12} \mathrm{~F} / \mathrm{m}$ is the vacuum permittivity, $\varepsilon_{\mathrm{r}}$ : the relative permittivity of the dielectric material, $f(t)$ : the response function of the dielectric material.

Simplified diagram of the polarization/depolarization current measurement for the test object is shown in Figure 1a [7]. Figure 1b shows a typical polarization and depolarization current due to a step charging voltage $U_{\mathrm{C}}$ [7]. Assuming that a dc step voltage $u(t)$ with the following characteristics is applied to a totally discharged test object.

$$
u(t)=\left\{\begin{array}{cc}
0 & t<0 \\
U c & 0 \leq t \leq t_{1} \\
0 & t_{1}<t
\end{array}\right.
$$

As shown in Figure $1 \mathrm{~b}, T_{\mathrm{p}}$ which is from $t=0$ to $t_{1}$ represents the polarization duration time, and $T_{\mathrm{d}}$ the depolarization duration time. When $t<0$, the current through the test object is zero, and for time $0 \leq t \leq t_{1}$ the so called polarization current is generated due to the conductivity and the various polarization processes of the test object. The polarization current can be written as:

$$
i_{\text {pol }}(t)=C_{0} U_{c}\left[\frac{\sigma}{\varepsilon_{0}}+f(t)\right]
$$

At time $t=t_{1}$, the external voltage is removed and the test object is short circuited, the depolarization current can be expressed as:

$$
i_{\text {dep }}(t)=-C_{0} U_{c}\left[f(t)-f\left(t+t_{p}\right)\right]
$$

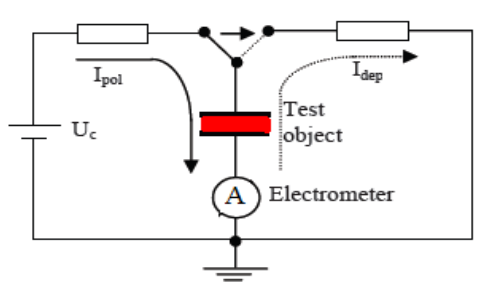

(a)

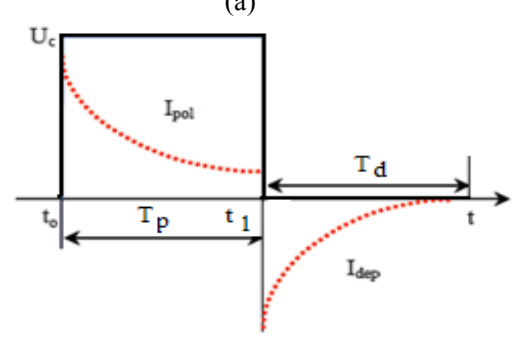

(b)

Figure 1. Principle of PDC measurement.

\section{EXPERIMENTAL}

\subsection{EXPERIMENT MATERIALS}

The mineral oil used in this experiment was Karamay No. 25 naphthenic mineral oil provided by Chuanrun Lubricant Co. Ltd, China. It has good electrical properties and oxidation stability, which satisfies the ASTM D3487-2000(II). The natural ester used in this research was BIOTEMP natural ester provided by ABB Chongqing Transformer Co. Ltd. The main parameters of the mineral oil and natural ester are shown in Table 1.

The insulation windings used in transformer were also provided by ABB Chongqing Transformer Co. Ltd. There are ten layers common Kraft cellulose insulation paper $(75 \mu \mathrm{m}$ 
thickness) wrapped the copper plate (width $2.8 \mathrm{~cm}$, thickness $0.2 \mathrm{~cm})$. The windings were cut short according to the dimension shown in Figure $2 \mathrm{a}$, and the real winding sample used for PDC measurement is shown in Figure $2 \mathrm{~b}$. The aluminum foil was wrapped outside the insulation paper to get a good measurement result. When the windings aged in oil were measured by PDC equipment, the windings were firstly dealt with in vacuum condition like the sample shown in Figure $2 b$.

Table 1. Typical parameters of mineral oil and natural ester used in the experiment.

\begin{tabular}{l|l|l}
\hline Property & Mineral oil & Natural ester \\
\hline Density, $\mathrm{kg} / \mathrm{m}^{3}$ & 884.6 & 910 \\
Kinematic viscosity $(40$ & 9.652 & 45 \\
$\left.{ }^{\circ} \mathrm{C}\right), \mathrm{mm}^{2} / \mathrm{s}$ & & \\
Pour point, ${ }^{\circ} \mathrm{C}$ & $<-24$ & -15 to -25 \\
Flash point, ${ }^{\circ} \mathrm{C}$ & 143 & 330 \\
Acidity, $\mathrm{mg} \mathrm{KOH} / \mathrm{g}$ & $<0.01$ & 0.075 \\
Water content, $\mathrm{mg} / \mathrm{kg}$ & 13 & 42 \\
Breakdown voltage $(2.5$ & & \\
mm gap electrode, $\mathrm{kV}$ & 38 & 52 \\
Corrosive sulfur & Non- & Non- \\
& corrosive & corrosive \\
\hline
\end{tabular}

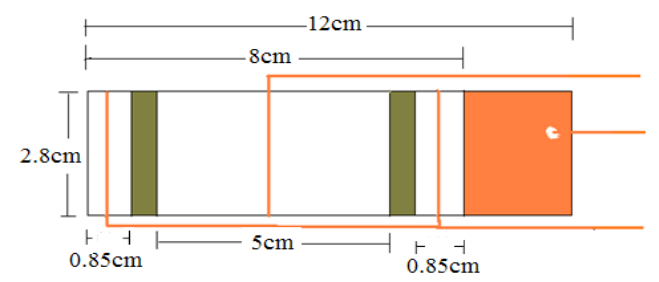

(a) dimension of the sample

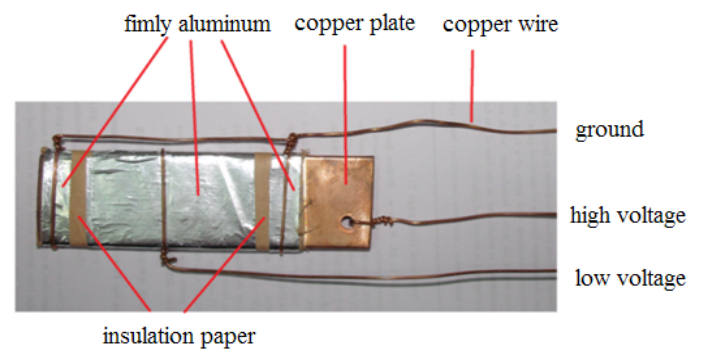

(b) real object

Figure 2. Sample for PDC measurement.

\subsection{THERMAL AGEING EXPERIMENT OF OIL-PAPER INSULATION SAMPLES}

In this paper, accelerated thermal ageing experiment of windings immersed in natural ester and mineral oil at $110{ }^{\circ} \mathrm{C}$ was conducted as shown in Figure 3. Firstly, in order to simulate the real ageing conditions in modern sealed transformers, all winding samples and pressboards were put into a vacuum box and were dried at $90{ }^{\circ} \mathrm{C}$. Then the temperature of the vacuum box was adjusted to $40{ }^{\circ} \mathrm{C}$. Secondly, the new degassed mineral oil or natural ester was infused into the vacuum box. The vacuum box was left for 24 $\mathrm{h}$ at $40{ }^{\circ} \mathrm{C}$ and then cooled down to room temperature. Thirdly, three winding samples and $38 \mathrm{~g}$ pressboard samples were taken out of the vacuum box each time and put into a glass bottle $(1000 \mathrm{ml})$. Then new mineral oil (or new natural ester) was poured into each bottle at a mass weight ratio of liquid/cellulose materials equal to $10: 1$ (each bottle has $630 \mathrm{~g}$ oil and $63 \mathrm{~g}$ cellulose materials). Then every bottle was filled up with nitrogen and sealed. These bottles were finally put into the ageing oven and heated to $110^{\circ} \mathrm{C}$ for the accelerated thermal ageing experiment.

The initial absolute moisture content of the oil and paper were measured by Karl Fischer Titration method. The relative moisture for oil is the dissolved moisture content of the oil relative to the maximum capacity of moisture that the oil can hold. The relative moisture $\mathrm{W}_{\text {rel }}$ at a given temperature $T$ is defined in terms of the actual moisture content in a liquid $\mathrm{W}_{\mathrm{abs}}$ versus the saturation limit $\mathrm{W}_{\mathrm{L}}(T)$ [24], as following:

$$
W_{r e l}=\frac{W_{a b s}}{W_{L}(T)}
$$

At room temperature, the initial moisture content of new mineral oil and new natural ester are $13 \mathrm{mg} / \mathrm{Kg}$ and $42 \mathrm{mg} / \mathrm{Kg}$, respectively. The saturation limits of natural ester and mineral oil are about 3000 and $60 \mathrm{mg} / \mathrm{Kg}$ at room temperature [25]. According to equation (1), the relative moisture content of natural ester and mineral oil is about $1.40 \%$ and $21.7 \%$, respectively. The initial moisture content of paper in the windings immersed in natural ester and mineral oil are all at $2.0 \%$.

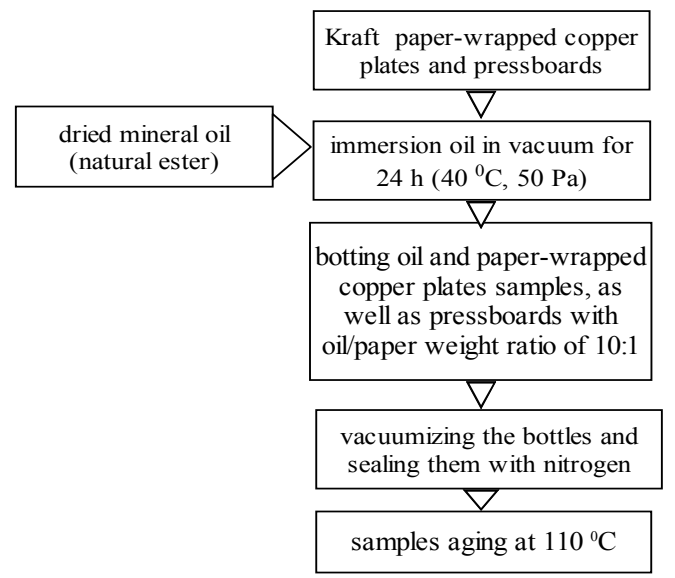

Figure 3. Thermal ageing experiment flowchart.

\subsection{PDC MEASUREMENT}

The PDC measurements of windings aged in natural ester and mineral oil for different times were performed using PDCanalyser-1MOD, ALFF Engineering, Switzerland. The current measurement accuracy of this system is $0.5 \%$ of the measured value $\pm 1 \mathrm{pA}$ after 1 hour warming up. The experiments were done at charging voltage $U_{\mathrm{c}}=200 \mathrm{~V}$, testing temperature $T=27$ $\pm 0.1^{\circ} \mathrm{C}$. Due to nature of the polarization species involved in real transformer insulation, a perfect PDC measurement would take a very long time, to allow all the interfacial polarization species to be relaxed. Test duration of 10,000 s charging and $10,000 \mathrm{~s}$ discharging has been considered a reasonable compromise in the context of power transformer insulation [26]. In the PDC-ANALYSER-1MOD User's Guide [27], it says that the polarization duration of 5000 to 7000 seconds is sufficient to assess the insulation quality of a power transformer, the same duration is also recommended for the depolarization duration. The PDC measurements on the CIGRE model and on a distribution transformer with different 
charging/discharging time i.e. $1000 / 1000$ s, $2000 / 2000$ s, $3000 / 3000 \mathrm{~s}, \quad 5000 / 5000 \mathrm{~s}$ and $10,000 / 10,000 \mathrm{~s}$ were conducted. Both the current difference and charge difference methods have been adopted [26]. The authors believe that charging and discharging time of $3000 / 3000 \mathrm{~s}$ would be acceptable. In this study, the structure of the winding is simple compared to the transformer model or the real transformer. On the other hand, for a linear dielectric, when the charging time is sufficiently long, the difference between polarization and depolarization currents equals to the conduction current [26]. It found that the difference between polarization and depolarization currents for the new winding immersed in mineral oil and natural ester remains constant when the testing time longer than $1000 \mathrm{~s}$ (calculated from the data shown in Figures 4 and 5). A similar observation has been found in [26]. The duration of $5000 \mathrm{~s}$ charging and 5000 $\mathrm{s}$ discharging was selected in this experiment.

The aged sample was gradually cooled down to room temperature in vacuum box for two months to obtain the room-temperature equilibrium distribution between cellulose and oil. Then the oil conductivity and moisture content of the oil- paper insulation samples during the ageing process were directly measured. The oil conductivity was measured according to ASTM D1169-11. The absolute moisture content of paper was measured using Karl Fischer Titration method. When the PDC measurement was conducted, the winding and insulation oil together after ageing for different time intervals were contained in a column bottle $(1000 \mathrm{ml})$, and $400 \mathrm{ml}$ insulation oil was infused to immerse the winding. Then the bottle was sealed with plastic film. And the copper wire was wrapped with plastic insulation pipe. When the PDC measurement at different temperature was conducted, the bottle contained winding and insulation oil was put into temperature controlled room with the accuracy of $\pm 0.1{ }^{\circ} \mathrm{C}$. The PDC measurements at $40,55,70,85$ and $100{ }^{\circ} \mathrm{C}$ were also investigated to study the influence of temperature. The winding immersed in natural ester is defined as natural-ester paper insulation sample, and the winding immersed in mineral oil is defined as mineral oil-paper insulation sample in the following sections.

\section{EXPERIMENTAL RESULTS}

\subsection{PDC BEHAVIOR OF OIL-PAPER INSULATION SAMPLES WITH DIFFERENT AGEING CONDITION}

PDC measured at different ageing intervals on the natural ester paper-insulation sample and mineral oil-paper insulation sample are shown in Figures 4 and 5. The polarity of the depolarization current values has been changed to positive values for easy comparison. It can be seen from Figures 4 and 5 that the polarization/depolarization current of the natural ester paper-insulation sample and mineral oil-paper insulation sample has a different pattern in the ageing process.

The polarization/depolarization current of natural ester-paper insulation sample reaches a relative stable current value earlier than that of mineral oil-paper insulation sample. In addition, the polarization/depolarization current of natural ester-paper insulation sample is higher than that of mineral oil-paper insulation sample with the same ageing intervals. For mineral

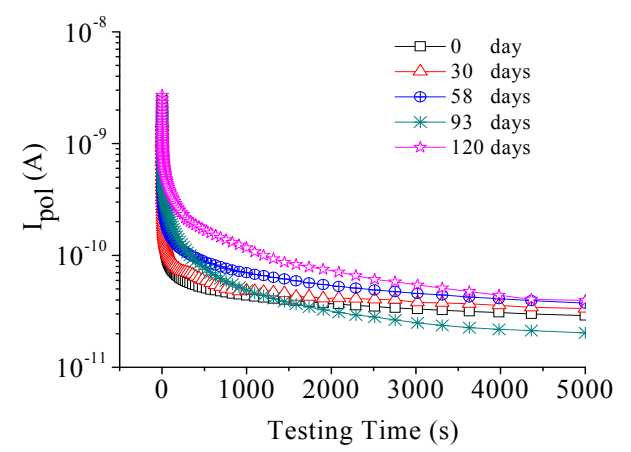

(a) polarization current

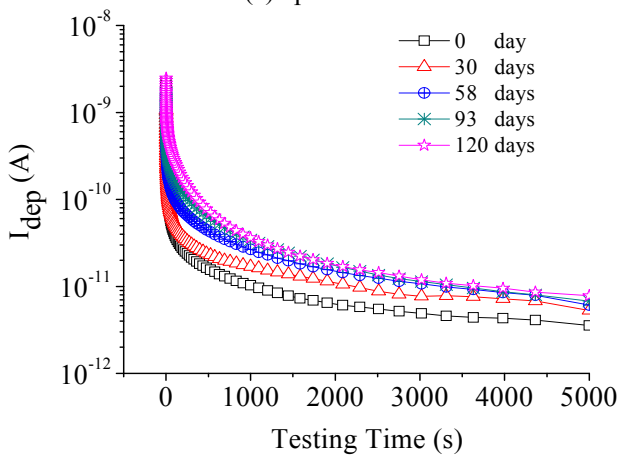

(b) depolarization current

Figure 4. PDC measurements on the mineral oil-paper insulation sample with different ageing condition.

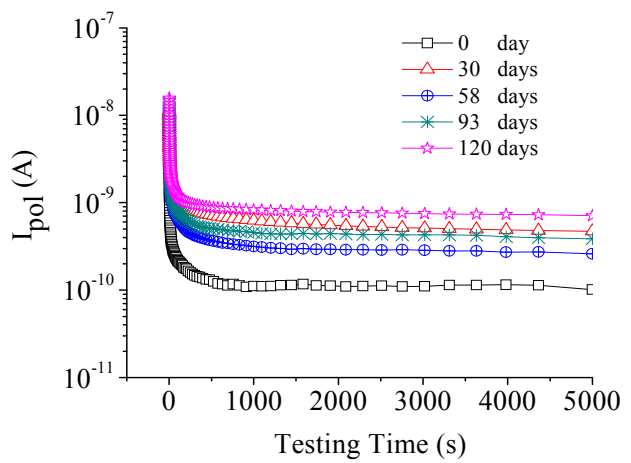

(a) polarization current

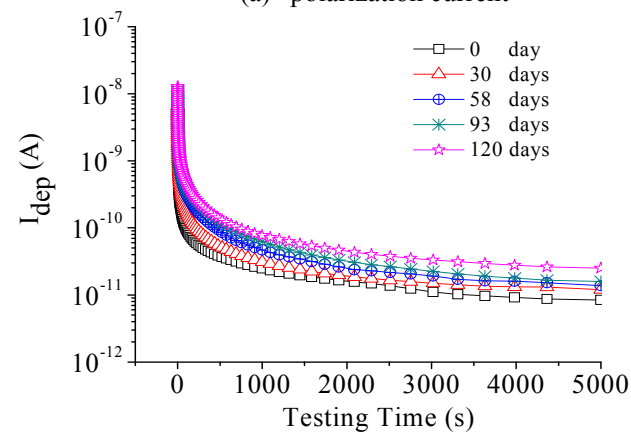

(b) depolarization current

Figure 5. PDC measurements on the natural ester-paper insulation sample with different ageing condition.

oil-paper insulation sample, the long term polarization current value increases with the ageing time increased except for the sample aged for 93 days. While the long term depolarization current of mineral oil-paper insulation sample increases with the ageing time all the time. For natural ester-paper insulation sample, apart from the sample aged for 30 days, the long term polarization current value of natural ester-paper insulation 
sample increases all the time over the ageing period. The long term depolarization current value of natural ester-paper insulation sample also increases all the time with the ageing. As shown in Figures $4 \mathrm{a}$ and $5 \mathrm{a}$, the polarization current values decreases for mineral oil-paper insulation sample aged for 93 days and increases for natural ester-paper insulation sample aged for 30 days may mainly cause by the migration of byproducts between oil and paper $[12,28]$.

The absolute moisture content of oil and paper during the ageing process are shown in Figures 6 and 7. The samples aged for different times were gradually cooled down from 110 ${ }^{\circ} \mathrm{C}$ to room temperature, and placed two months hermetically at temperature controlled vacuum box to make the ageing products obtain the room-temperature equilibrium distribution between cellulose and oil. After that the moisture content of the aged oil-paper insulation sample and the PDC measurement were all conducted at room temperature $27^{\circ} \mathrm{C}$. When the PDC measurement conducted, the sample was sealed. The moisture content of the oil-paper insulation sample before and after the PDC measurements almost the same.

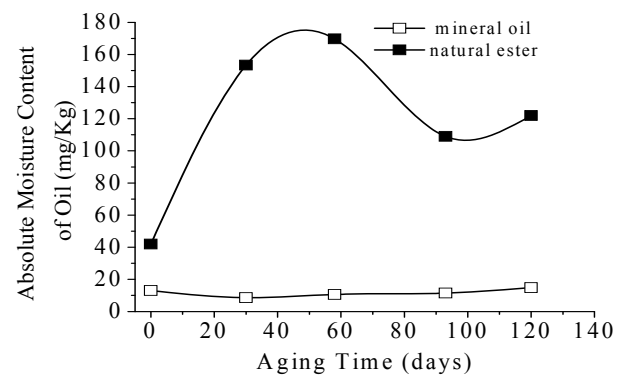

Figure 6. Absolute moisture content of natural ester and mineral oil in the ageing process.

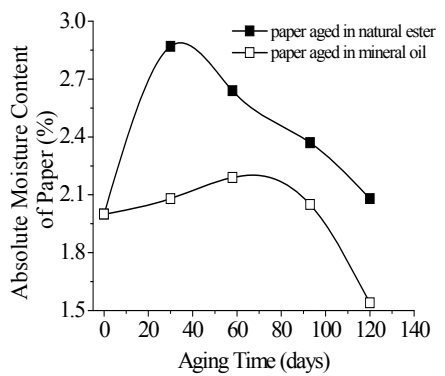

Figure 7. Absolute moisture content of paper aged in natural ester and mineral oil

It is expected that the moisture content of the paper would increase after the ageing period due to the degradation of the oil-paper insulation. However, moisture tends to flow out from higher concentrations towards lower concentrations. The moisture contents of the three different mediums inside the bottles-paper, oil and air always tend towards an equilibrium position with respect to moisture [12,29].

The absolute moisture content of natural ester increases initially and then decreases, lastly increases again slightly when the ageing time increases. When sampled at 58 days, the moisture content of natural ester increased to $170 \mathrm{mg} / \mathrm{Kg}$, which is the maximum. While the absolute moisture content of mineral oil has a slight decrease at first, and then increases all the time. Figure 6 indicates that the natural ester has much higher absolute moisture content than mineral oil after experiencing the same ageing length. This is because natural ester has a greater affinity for moisture than does mineral oil $[31,32]$. The conductivity of the natural ester and mineral oil is shown in Table 2. It can be seen from Table 2 that natural ester also has much higher oil conductivity than mineral oil in the ageing process.

Table 2. Oil conductivity during the ageing process.

\begin{tabular}{l|l|l|l|l|l}
\hline \multicolumn{1}{c|}{ Sample } & $0 \mathrm{~d}$ & $30 \mathrm{~d}$ & $58 \mathrm{~d}$ & $93 \mathrm{~d}$ & $120 \mathrm{~d}$ \\
\hline $\begin{array}{l}\text { Natural ester } \\
\text { conductivity }\left(10^{-10} \mathrm{~S} / \mathrm{m}\right)\end{array}$ & 3.73 & 3.08 & 3.55 & 6.62 & 22.9 \\
\hline $\begin{array}{l}\text { Mineral oil } \\
\text { conductivity }\left(10^{-11} \mathrm{~S} / \mathrm{m}\right)\end{array}$ & 0.58 & 2.77 & 1.87 & 2.65 & 4.57 \\
\hline
\end{tabular}

The absolute moisture content of the oil impregnated paper is shown in Figure 7. Moisture moves between the insulation paper and insulation oil to reach equilibrium in terms of relative saturation $[12,29,30]$. The moisture content of natural ester impregnated paper increase with the ageing time firstly. When sampled at 30 days, the moisture content of paper aged in natural ester increases to $2.87 \%$, which is the maximum in the thermal ageing process. This is why the polarization current of natural-ester paper insulation sample increases a lot, as shown in Figure 5a. However, moisture reacts with the natural ester via hydrolysis. The reaction consumes dissolved moisture in the fluid causing additional moisture to move from the paper into the fluid in order to maintain the equilibrium. Hence, the moisture content of paper aged in natural ester reduces after ageing 30 days.

In mineral oil/paper insulation system, the moisture content of paper also increases because of oil/paper insulation deterioration generating moisture. The moisture content of the mineral oil impregnated paper increases firstly. However, when the oil and the air inside the bottles being relatively drier than the moisture condition of paper, there is always a migration of moisture from the paper to the oil and then to the air $[12,29]$. Thus the moisture content of paper has a decline. The longer the periods of ageing, the larger is the amount of moisture migrating out from the paper [12]. Therefore, the moisture content of the paper aged in mineral oil also shows a decrease after ageing 93 days. This may contribute the decrease of the polarization current of the mineral oil-paper sample, as shown in Figure 4a.

The dielectric measurement results are influenced by the oil conductivity, dielectric response function and the paper conductivity. Greater mobility of charge carriers in the liquid dielectric can be attributed to the higher initial charging currents, after a while, the initial inrush current goes to zero and steady conduction current is recorded due to the lower mobility of charge carriers in the solid insulation [32]. The long term $\mathrm{dc}$ conduction current from the polarization measurement normally relates to the paper conductivity, while the short term current magnitude relates to the oil conductivity $[7,23,28]$. For typical measuring conditions the conductivity of the oil affects the polarization current mainly in a time range $t<100 \mathrm{~s}$. A higher oil conductivity leads to a higher initial current. The paper insulation conductivity has dominant effect on its polarization characteristic mainly in the time range $t>1000 \mathrm{~s}[7,23,28]$. A higher conductivity of the paper also leads to a higher long term current. The initial 
polarization/depolarization current values $(t=2.5 \mathrm{~s})$ and the long term current values $(\mathrm{t}=5000 \mathrm{~s})$ of the oil-paper samples are shown in Figure 8. It clearly shows that the initial polarization/depolarization current of natural ester-paper insulation sample is much higher than that of mineral oil-paper insulation sample in the ageing process. The long term polarization/depolarization current of natural ester-paper insulation sample is also much higher than that of mineral oilpaper insulation sample in the ageing process. The results shown in Figure 8 are consistent with the higher oil conductivity and moisture content of paper aged in natural ester.

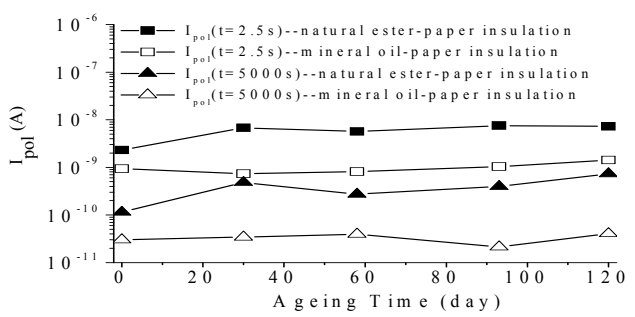

(a) polarization current

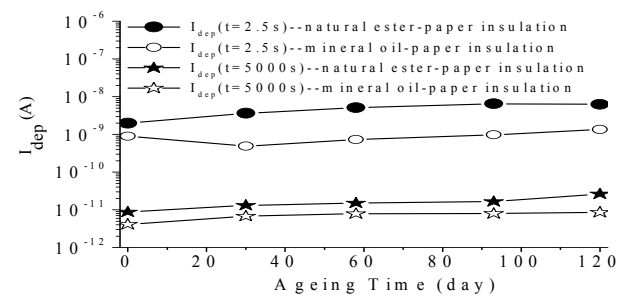

(b) depolarization current

Figure 8. Initial polarization/depolarization current values $(\mathrm{t}=2.5 \mathrm{~s})$ and long term polarization/depolarization current values $(\mathrm{t}=5000 \mathrm{~s})$ of the natural esterpaper insulation sample and mineral oil-paper insulation sample.

According to Saha et al [12], the electrical techniques may be not very sensitive to measure the extent of aging of paper/pressboard insulation. As shown in Figures $4 \mathrm{a}$ and 5a, ageing products has great effect on the polarization current due to the polarization current is the summation of polarization current and the conductivity current (equation (3)). However, the depolarization current mainly relate to the response function of the dielectric material, as shown in equation (4). The degradation of polymeric insulation systems increases the space charge density and the concentration of electrical dipoles. From Figures $4 b$ and $5 b$, it is noteworthy that the amplitude of long term depolarization current is sensitive to the ageing condition of oil-paper insulation samples. The longer the ageing time, the higher amplitude the depolarization current values of natural ester-paper insulation sample and mineral oil-paper insulation sample. However, it is difficult to make quantitative analysis the ageing status of oilpaper insulation samples using depolarization current values. In the following, a new method to relate ageing condition and the PDC result by calculating the depolarization charge quantity of oil-paper insulation samples is proposed.

\subsection{METHOD FOR CALCULATING THE DEPOLARIZATION CHARGE QUANTITY}

It is commonly known that dielectrics with alternating layer of oil and paper can be simulated with R-C equivalent circuit model [21-23]. The polarization processes inside the oil-paper insulation structure can be modeled by a parallel arrangement of branches each containing a series connection of resistor and capacitor as shown in the circuit of Figure 9.

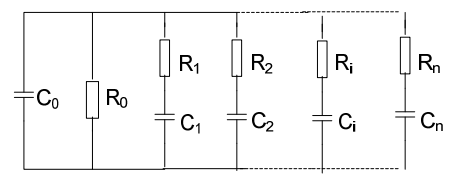

Figure 9. R-C equivalent circuit model

The circuit parameters shown in Figure 9 can be derived from measured polarization and depolarization currents $\left(i_{\mathrm{pol}}\right.$ and $i_{\text {dep }}$ ). The capacitance $C_{0}$ is determined by conventional capacitance measurement techniques at power frequency. The insulation resistance $R_{0}$ is calculated from the difference between polarization and depolarization currents at larger values of time. These polarization processes, represented as $R_{\mathrm{i}}-C_{\mathrm{i}}$, are randomly distributed, and have associated time constants given by $\tau_{\mathrm{i}}=R_{\mathrm{i}} C_{\mathrm{i}}$. The individual elements $R_{\mathrm{i}}-C_{\mathrm{i}}$ with the corresponding time constants $\tau_{\mathrm{i}}=R_{\mathrm{i}} C_{\mathrm{i}}$ can be determined by fitting the depolarization current with the following equation:

$$
\begin{aligned}
i_{\text {dep }}(t) & =\sum_{i=1}^{n}\left(A_{i} * e^{-\frac{t}{\tau_{i}}}\right) \\
A_{i} & =U_{c} * \frac{1-e^{-\frac{T_{p}}{\tau_{i}}}}{R_{i}}
\end{aligned}
$$

where, $n=$ number of $R_{\mathrm{i}}-C_{\mathrm{i}}$ branches, $T_{\mathrm{p}}=$ polarization time and $U_{\mathrm{C}}=$ applied de voltage magnitude.

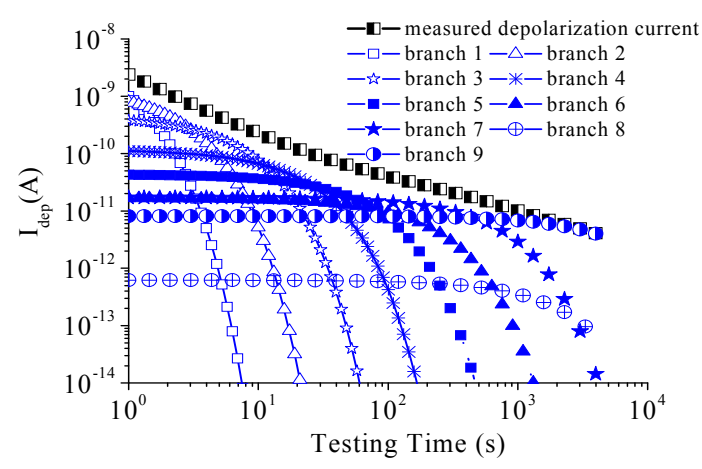

Figure 10. Individual elements of the depolarization current.

Figure 10 shows the result of the analytic fitting method. The black line in Figure 10 is the depolarization current of new short winding (Figure $4 \mathrm{~b}$ ) immersed in new mineral oil measured at $27 \pm 0.1{ }^{\circ} \mathrm{C}, U_{\mathrm{c}}=200 \mathrm{~V}, T_{\mathrm{p}}=5000 \mathrm{~s}$. The blue lines in Figure 10 are the individual elements fitted the depolarization current according to equations (5) and (6), and the $R_{\mathrm{i}}-C_{\mathrm{i}}$ values are shown in Table 3 . The depolarization current measured and the depolarization current simulated by equations (5) and (6) according to the data in Table 3 is shown in Figure 11. It can be seen that it performs satisfactory. The $\mathrm{R}^{2}$ value is higher than $0.99\left(R^{2}\right.$ is the coefficient of determination, which is used to measure how successful the fit is in explaining the variation of the data. $R^{2}$ value closer to 1 indicates a better fit). The experimental result and the $R-C$ circuit model simulation result are in good agreement with each other. 
Table 3. The fitting parameters of curve for simulating.

\begin{tabular}{l|l|l|l|l}
\hline Branches & $\tau_{\mathrm{i}}(\mathrm{s})$ & $\mathrm{A}_{\mathrm{i}}$ & $\mathrm{R}_{\mathrm{i}}(\Omega)$ & $\mathrm{C}_{\mathrm{i}}(\mathrm{F})$ \\
\hline 1 & 0.562 & $5.94 \times 10^{-9}$ & $3.36 \times 10^{10}$ & $1.67 \times 10^{-11}$ \\
2 & 1.78 & $1.41 \times 10^{-9}$ & $1.41 \times 10^{11}$ & $1.26 \times 10^{-11}$ \\
3 & 5.62 & $4.56 \times 10^{-10}$ & $4.39 \times 10^{11}$ & $1.28 \times 10^{-11}$ \\
4 & 17.8 & $1.17 \times 10^{-10}$ & $1.71 \times 10^{12}$ & $1.04 \times 10^{-11}$ \\
5 & 56.2 & $4.35 \times 10^{-11}$ & $4.6 \times 10^{12}$ & $1.22 \times 10^{-11}$ \\
6 & 178 & $1.67 \times 10^{-11}$ & $1.2 \times 10^{13}$ & $1.49 \times 10^{-11}$ \\
7 & 562 & $1.72 \times 10^{-11}$ & $1.16 \times 10^{13}$ & $4.84 \times 10^{-11}$ \\
8 & 1780 & $6.20 \times 10^{-13}$ & $3.03 \times 10^{14}$ & $5.87 \times 10^{-12}$ \\
9 & 5620 & $8.14 \times 10^{-12}$ & $1.45 \times 10^{13}$ & $3.88 \times 10^{-10}$ \\
\hline
\end{tabular}

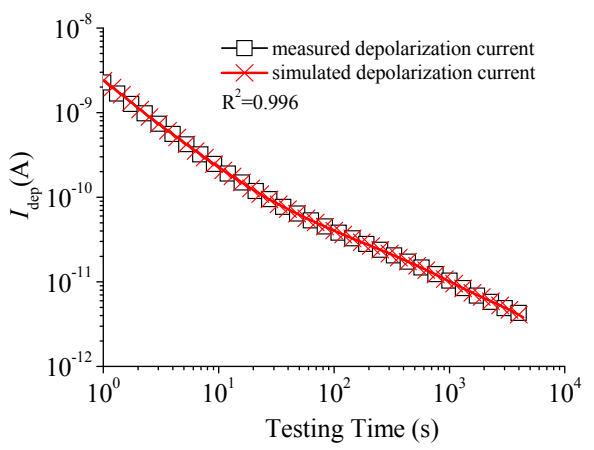

Figure 11. Comparison of measured and simulated curves of depolarization current.

The R-C equivalent circuit parameters with nine branches calculated out by fitting the depolarization current according to equations (5) and (6) for the mineral oil-paper insulation samples and natural ester-paper insulation samples with different ageing condition are shown in Appendix $\mathrm{A}$ and Appendix $B$, respectively. The $R^{2}$ values for every sample is higher than 0.99. From the data in the Appendix A and Appendix B, the multi-exponential equations of the depolarization current of mineral oil-paper insulation sample and natural ester-paper insulation sample with different ageing conditions can be obtained according to equations (5) and (6). Then the depolarization charge quantity for different samples could be calculated as follows:

$$
Q(t)=\int_{1}^{5000} I_{d e p}(t) d t
$$

where $t$ is the testing time, $1 \leq t \leq 5000 \mathrm{~s}$.

\subsection{QUANTITATIVE RELATION BETWEEN DEPOLARIZATION CHARGE QUANTITY AND AGEING STATUS OF OIL-PAPER INSULATION SAMPLES}

The depolarization charge quantity results of natural esterpaper insulation sample and mineral oil-paper insulation sample with different ageing conditions are shown in Figure 12. It can be seen from Figure 12 that the depolarization charge quantity of oil-paper insulation sample is very sensitive to its ageing condition. The more deterioration of the oil-paper insulation sample, the faster the increasing rate of the depolarization charge quantity, and the higher the value of the depolarization charge quantity saturation. In addition, Figure 12 clearly shows that the depolarization charge quantity of natural ester-paper insulation sample is higher than that of mineral oil-paper insulation sample aged for the same time due to its higher depolarization current values. The relationship between the depolarization charge quantity and the testing time is shown in Table 4 and Table $5\left(\mathrm{R}^{2}>0.97\right)$. For each oil-paper insulation sample, it can be seen that the depolarization charge quantity increases in an exponential way $Q(t)=\mathrm{C}+\mathrm{A}^{*} \exp ^{(-t / \mathrm{B})}$ with the testing time. $Q_{0}(\mathrm{t})$ means the depolarization charge quantity of the oil-paper insulation sample aged 0 day, $Q_{30}(\mathrm{t})$ means the depolarization charge quantity of the oil-paper insulation sample aged 30 days, etc.

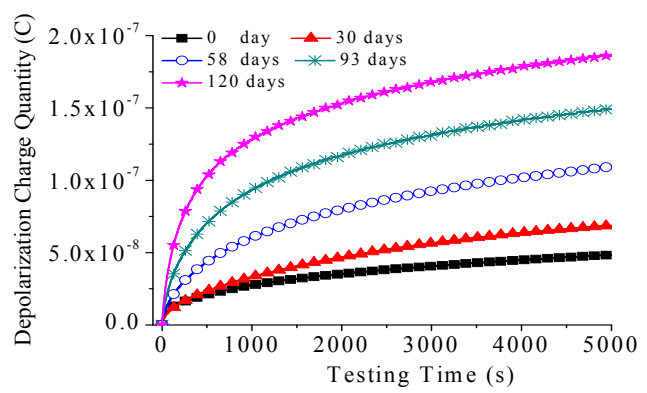

(a) mineral oil-paper insulation sample

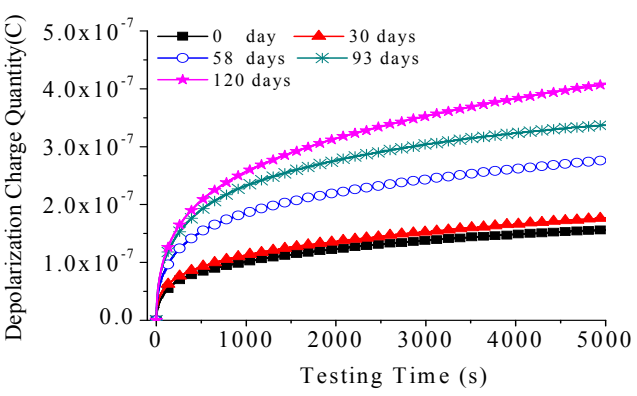

(b) natural ester-paper insulation sample

Figure 12. Depolarization charge quantity results of oil-paper insulation sample with different ageing condition.

Table 4. Relation between the depolarization charge quantity and testing time for natural ester-paper insulation sample in the ageing process.

\begin{tabular}{r|l|l}
\hline Ageing time & Fitting equations $\mathrm{Q}(t)=\mathrm{C}+\mathrm{A}^{*} \exp ^{(-t / \mathrm{B})}$ & $\mathrm{R}^{2}$ \\
\hline 0 & $Q_{0}(t)=1.5793 * 10^{-7}-1.0807 * 10^{-7} * \exp ^{(-t / 1676.18)}$ & 0.981 \\
\hline 30 & $Q_{30}(t)=1.7972 * 10^{-7}-1.2182 * 10^{-7} * \exp ^{(-t / 1856.67)}$ & 0.980 \\
\hline 58 & $Q_{58}(t)=2.7357 * 10^{-7}-1.8443 * 10^{-7} * \exp ^{(-t / 1496.36)}$ & 0.974 \\
\hline 93 & $Q_{93}(t)=3.3234 * 10^{-7}-2.2710^{*} 10^{-7} * \exp ^{(-t / 1318.55)}$ & 0.972 \\
\hline 120 & $Q_{120}(t)=4.1017 * 10^{-7}-2.9336^{*} 10^{-7} * \exp ^{(-t / 1698.04)}$ & 0.980 \\
\hline
\end{tabular}

Table 5. Relation between the depolarization charge quantity and testing time for mineral oil-paper insulation sample in the ageing process.

\begin{tabular}{r|l|l}
\hline Ageing Time & Fitting equations $\mathrm{Q}(\mathrm{t})=\mathrm{C}+\mathrm{A}^{*} \exp ^{(-t / \mathrm{B})}$ & $\mathrm{R}^{2}$ \\
\hline 0 & $\mathrm{Q}_{0}(\mathrm{t})=5.0634 \mathrm{E}-8-3.8789 * 10^{-8} * \exp ^{(-t / 2082.22)}$ & 0.991 \\
\hline 30 & $\mathrm{Q}_{30}(\mathrm{t})=7.6254 \mathrm{E}-8-6.6487 * 10^{-8 *} \exp ^{(-t / 2413.37)}$ & 0.997 \\
\hline 58 & $\mathrm{Q}_{58}(\mathrm{t})=1.1253 * 10^{-7}-9.4359 * 108^{*} \exp ^{(-t / 1826.9)}$ & 0.992 \\
\hline 93 & $\mathrm{Q}_{93}(\mathrm{t})=1.4733 * 10^{-7}-1.1833^{*} 10^{-7} * \exp ^{(-t / 1371.97)}$ & 0.986 \\
\hline 120 & $\mathrm{Q}_{120}(\mathrm{t})=1.8078 * 10^{-7}-1.3487 * 10^{-7} * \exp ^{(-t / 135.3)}$ & 0.974 \\
\hline
\end{tabular}

In order to make quantitative analysis of the depolarization charge quantity of oil-paper insulation sample and its ageing condition, the degree of polymerization $(D P)$ of the paper on the winding aged in natural ester and mineral oil was measured according to ASTM D4243-99. DP values of paper aged in natural ester and mineral oil are shown in Figure 13. $D P$ values of paper aged in natural ester and mineral oil 
decrease fast in the initial ageing stage due to the high moisture content of the insulation paper. It can be seen that the paper aged in natural ester has higher $D P$ values than that aged in mineral oil in the ageing process due to the protecting role of the natural ester to the cellulose insulation paper [16-19].

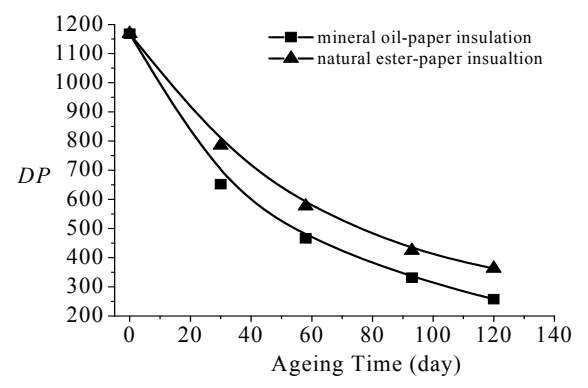

Figure 13. DP of paper aged in natural ester and mineral oil.

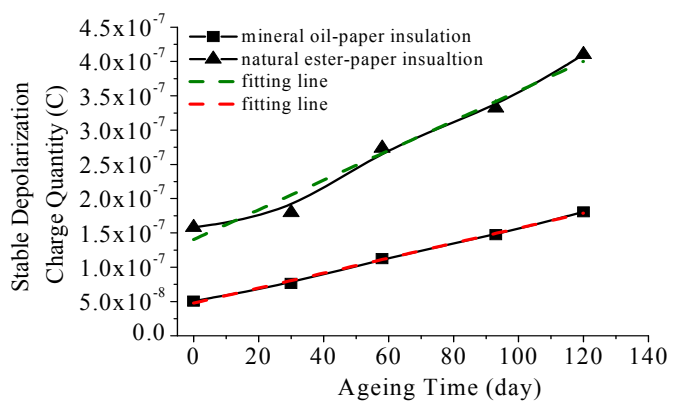

Figure 14. Stable depolarization charge quantity of oil-paper insulation sample and ageing time

Table 6. Stable depolarization charge quantity of oil-paper insulation sample and its ageing tine.

\begin{tabular}{c|c|c}
\hline Sample & Fitting equations $\mathrm{Q}_{\text {stable }}(\mathrm{t})=\mathrm{a}^{*} \mathrm{t}+\mathrm{b}$ & $\mathrm{R}^{2}$ \\
\hline $\begin{array}{c}\text { Natural ester- } \\
\text { paper insulation }\end{array}$ & $\mathrm{Q}_{\text {stable }}(\mathrm{t})=2.164 * 10^{-9 *} \mathrm{t}+1.405^{*} 10^{-7}$ & 0.964 \\
\hline $\begin{array}{c}\text { Mineral oil- } \\
\text { paper insulation }\end{array}$ & $\mathrm{Q}_{\text {stable }}(\mathrm{t})=1.093 * 10^{-9} * \mathrm{t}+4.773 * 10^{-8}$ & 0.996 \\
\hline
\end{tabular}

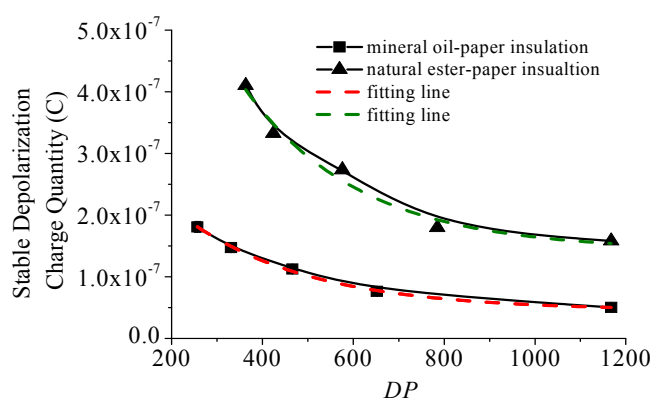

Figure 15. Stable depolarization charge quantity of oil-paper insulation sample and ageing condition

Table 7. Stable depolarization charge quantity of oil-paper insulation sample and DP of paper.

\begin{tabular}{c|l|c}
\hline Sample & Fitting equations Qstable(DP) $=\mathrm{E}^{*} \exp ^{(-\mathrm{DP} / \mathrm{F})}+\mathrm{D}$ & $\mathrm{R}^{2}$ \\
\hline $\begin{array}{c}\text { Natural ester- } \\
\text { paper insulation }\end{array}$ & $\mathrm{Q}_{\text {stable }}(\mathrm{DP})=1.09^{*} 10^{-6 *} \exp ^{(-\mathrm{DP} / 253.72)}+1.43^{*} 10^{-7}$ & 0.966 \\
\hline $\begin{array}{c}\text { Mineral oil- } \\
\text { paper insulation }\end{array}$ & $\mathrm{Q}_{\text {stable }}(\mathrm{DP})=3.44 * 10^{-7} * \exp ^{(-\mathrm{DP} / 275.81)}+4.55^{*} 10^{-8}$ & 0.997 \\
\hline
\end{tabular}

In Tables 4 and 5, the constant $C$ is defined as the stable depolarization charge quantity $Q_{\text {stable }}$ in this paper. The relationship between the stable depolarization charge quantity of oil-paper insulation sample and its ageing time, as well as $D P$ of paper has been investigated, as shown in Figure 14 and Table 6, Figure 15 and Table 7, respectively. From Figure 14 and Table 6, it can be clearly seen that the best fit for the $Q_{\text {stable }}$ and the ageing time of natural ester-paper insulation samples and mineral oil-paper insulation samples is linear $\left(\mathrm{R}^{2}>0.96\right)$. From Figure 15 and Table 7 , it also clearly shows that the best fit for the $Q_{\text {stable }}$ and $D P$ of paper aged in natural ester-paper insulation samples and mineral oil-paper insulation samples is exponential $\left(\mathrm{R}^{2}>0.96\right)$. Form Table 7 , it indicates that the DP could be induced by $D P=\mathrm{F}^{*}\left(\ln \mathrm{E}-\ln \left(\mathrm{Q}_{\text {stable }}-\mathrm{D}\right)\right)$. Therefore, the stable depolarization charge quantity can be used to predict the ageing condition of the oil-paper insulation samples.

Due to the high resistance of oil and paper, the depolarization currents in normal transformer are very smallin range of nA. The small current can be affected by induced ac currents, electromagnetic interferences and electrostatic induction from nearby high voltage installations. These effects are also aggravated by wind and humidity in open substations. Long test leads connecting the bushing to the testing instrument also add up to the problem of interference [33]. Besides, the PDC measurement is easy to affect by the noise. The depolarization current value is not good choice to select as aging index. In this study, the depolarization current of the winding was simulated by its $\mathrm{R}-\mathrm{C}$ circuit parameters. The simulated depolarization current is fitted very well with the measured depolarization current and the simulated depolarization current line is smooth. This smooth line contains almost the same information as the original line. This method can reduce the effect of the interference and noise in the field measurement. The depolarization charge quantity of the winding sample calculated from its $\mathrm{R}-\mathrm{C}$ parameters is also less sensitive to interference and noise, and is much more sensitive to the ageing condition than the depolarization current values. From the quantitative results presented Figure 15 and Table 7, it is shown that the depolarization charge quantity is a better choice to select as ageing index.

\subsection{PDC AT DIFFERENT TEMPERATURES}

In this experiment, firstly, six winding samples were put into a vacuum box and were dried at $90{ }^{\circ} \mathrm{C}$ for $24 \mathrm{~h}$. Secondly, all the dried winding samples were placed in the air for moisture absorption naturally. After absorbing the moisture for about 1 $\mathrm{h}$, three winding samples were impregnated by new mineral oil with moisture content $13 \mathrm{mg} / \mathrm{Kg}$. The other three winding samples were impregnated by new natural ester with moisture content $42 \mathrm{mg} / \mathrm{Kg}$. All the winding samples were impregnated by oil under vacuum condition at $40{ }^{\circ} \mathrm{C}$ for $24 \mathrm{~h}$. Then the samples were gradually cooled down to room temperature in vacuum box for two months to obtain the room-temperature equilibrium distribution between cellulose and oil. The moisture content of paper on the winding immersed in mineral oil and natural ester was measured by Karl Fischer Titration method before the PDC measurement. The insulation winding immersed in natural ester and mineral oil with moisture content of paper are $1.536 \%$ and $1.465 \%$ at $27{ }^{\circ} \mathrm{C}$ were selected. 
When the PDC measurement was conducted at 40, 55, 70, 85 and $100{ }^{\circ} \mathrm{C}$, The temperature was increased to each temperature and the sample was kept for two days, after that the PDC measurement was conducted. The insulation oil and insulation paper conductivity are known to vary with temperature $\mathrm{T}$ (in Kelvin) according to the well-known Arhenius relationship [28, 34]:

$$
\sigma=A \exp \left(-\frac{E_{\mathrm{ac}}}{\mathrm{kT}}\right)
$$

where $E_{a c}$ is the activation energy and $A$ is a constant related to ions mobility in the insulation. According to the equation published in $[28,35]$, the conductivity of the oil and paper can be calculated as following:

$$
\sigma_{0} \approx \frac{\varepsilon_{0}}{C_{0} U_{c}}\left(i_{\text {pol }}\left(t_{b}\right)-i_{\text {depol }}\left(t_{b}\right)\right) .
$$

The oil conductivity can be calculated with equation (10) where the $\mathrm{i}_{\text {pol }}\left(\mathrm{t}_{\mathrm{b}}\right)$ and $\mathrm{i}_{\text {depol }}\left(\mathrm{t}_{\mathrm{b}}\right)$ are the initial values in polarization and depolarization currents $[28,35]$. The conductivity of the paper can be estimated from the long term values of the polarization and depolarization currents, by replacing the $t_{b}$ with $t_{m}$, where $t_{m}$ represents the largest value of time that the currents have been measured, in this study $\mathrm{t}_{\mathrm{m}}=5000 \mathrm{~s}$. The oil conductivity and paper conductivity at $40,55,70,85$ and $100{ }^{\circ} \mathrm{C}$ are shown in Figure 16. It can be seen that both oil and paper conductivities increase exponentially with temperature. Moreover, increasing temperature also cause higher mobility of the dipoles [7]. All above cause the polarization/depolarization currents of mineral oil-paper sample and natural ester sample increase with the temperature, as shown in Figures 17 and 18.

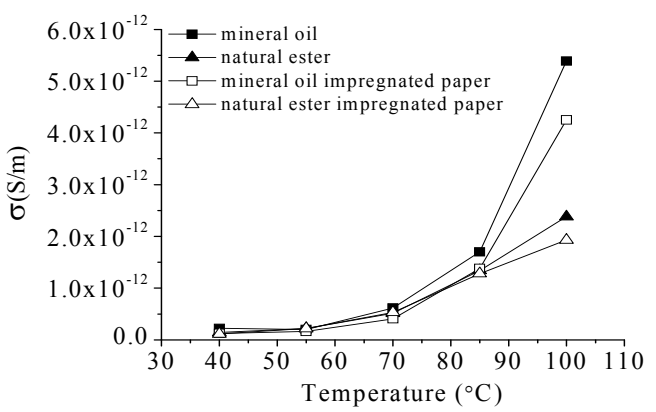

Figure 16. Conductivity of oil and paper changing with temperature.

Figures 17 and 18 show that at lower temperatures of $40{ }^{\circ} \mathrm{C}$ and $55{ }^{\circ} \mathrm{C}$, the polarization/depolarization current of natural ester-paper insulation sample is a little higher than that of mineral oil-paper insulation sample. However, at higher temperature of 85 and $100{ }^{\circ} \mathrm{C}$, the polarization/depolarization current of natural ester-paper insulation sample is a little lower than that of mineral oil-paper insulation sample. This is because the moisture moves from the cellulose to oil when the temperature increased [12, 29]. Compared with mineral oil, natural ester has much higher moisture saturation at 85 and $100{ }^{\circ} \mathrm{C}$ [25], which results in more moisture migrate from the paper to the natural ester, leading to the conductivity of the paper immersed in natural ester is lower at 85 and $100{ }^{\circ} \mathrm{C}$, as shown in Figure 16. On the other hand, due to the much higher moisture saturation of natural ester at 85 and $100{ }^{\circ} \mathrm{C}$, the relative moisture content of the natural ester is lower, which results in the conductivity of natural ester is also lower than mineral oil at 85 and $100{ }^{\circ} \mathrm{C}$.

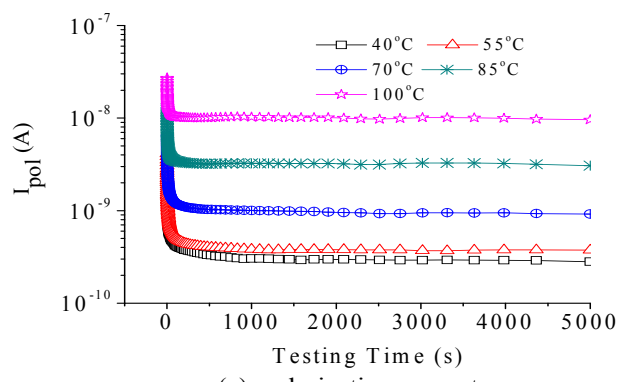

(a) polarization current

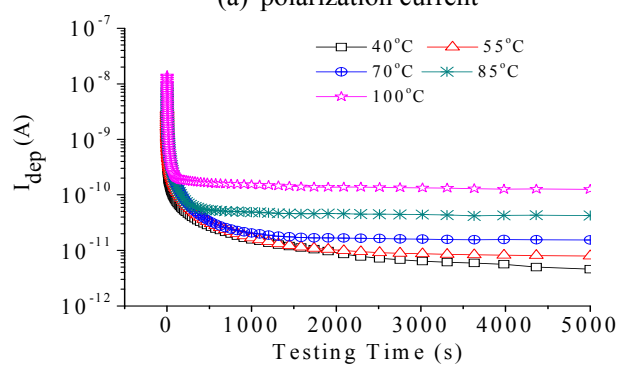

(b) depolarization current

Figure 17. PDC measurements on the mineral oil-paper insulation at different temperatures.

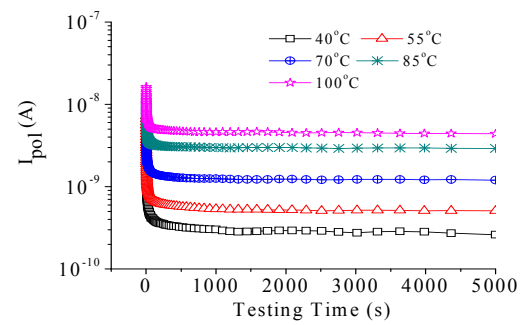

(a) polarization current

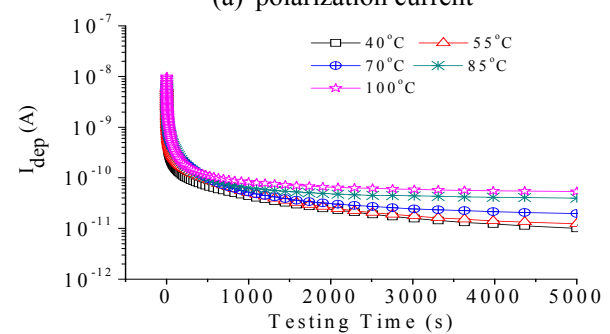

(b) depolarization current

Figure 18. PDC measurements on the natural ester-paper insulation at different temperatures.

Fofana et al [36] studied the effect of thermal transient on the polarization and depolarization current measurements of oil-paper insulation. According to [36], the parameters of the $\mathrm{R}-\mathrm{C}$ equivalent circuit could be extended to other temperatures according to the Arrhenius equation [36]. Then the polarization/depolarization current at different temperatures could be obtained. In this study, the parameters of $\mathrm{R}-\mathrm{C}$ equivalent circuit for oil-paper sample with different ageing condition at $27^{\circ} \mathrm{C}$ have been obtained, as shown in Appendix $\mathrm{A}$ and Appendix B. The parameters of $\mathrm{R}-\mathrm{C}$ equivalent circuit for oil-paper sample with different ageing condition at other temperatures could be got according to the method proposed in [36]. After that, the depolarization charge quantity for oilpaper sample with different ageing condition at other temperatures could be acquired.

The real transformer can also be presented by its $\mathrm{R}-\mathrm{C}$ equivalent circuit model. According to the method proposed in 
this study, the depolarization charge quantity for the real transformer could be calculated. According to the method proposed by [35], the temperatures effect could be resolved. However, different type of transformer has different geometry structure. If we can build a data base which relates the depolarization charge quantity to oil-paper insulation system with different ageing condition, different geometry and different testing temperature. Then hope the data base would be used to diagnose the real transformer.

\section{CONCLUSIONS}

Quantitative analysis of ageing status of natural ester-paper insulation and mineral oil-paper insulation by polarization/depolarization current has carried out by the PDC measurement on the natural ester-paper insulation sample and mineral oil-paper insulation sample aged at $110^{\circ} \mathrm{C}$ for 120 days. The following conclusions could be drawn from this research:

The polarization/depolarization current of the natural ester paper-insulation sample and mineral oil-paper insulation sample shows a different changing pattern in the ageing process. The polarization/depolarization current of natural ester-paper insulation sample is higher than that of mineral oilpaper insulation sample aged for the same intervals.

The depolarization charge quantity of both kinds of oil-paper insulation sample calculated out by their depolarization current is very sensitive to their ageing condition. The more deterioration of the oil-paper insulation sample, the higher the depolarization charge quantity. The depolarization charge quantity of natural ester-paper insulation sample is higher than that of mineral oil-paper insulation sample aged for the same time.

The stable depolarization charge quantity $Q_{\text {stable }}$ of natural ester-paper insulation sample and mineral oil-paper insulation sample increase in a linear way with the ageing time increased. The stable depolarization charge quantity can be used to predict the ageing condition of oil-paper insulation. There is an exponential relationship between the $Q_{\text {stable }}$ and $D P$ of paper aged in natural ester-paper insulation sample and mineral oil-paper insulation sample. It is worth to point out that the testing temperature should be better maintained when using the PDC technique to assess the condition of oil-paper insulation system.

This is our initial attempt to use the PDC technique to assess the ageing condition of transformer insulation. To apply the method to a real transformer more work is required. The transformer model with the alternative geometry structure has been designed in our laboratory. In the future work, the method to assess the ageing status of oil-paper insulation system proposed in this paper will be validated by the PDC measurement on the transformer model with different geometry structure, and the influence of geometry structure will also be considered.

\section{ACKNOWLEDGMENT}

The authors thank the Chinese National Basic Research 973 Program of China (2009CB724505-1) and the Scientific Research Foundation of SKL of Power Transmission and System Security (2007DA10512708103) for the financial support provided.

\section{Appendix A: R-C equivalent circuit parameters for mineral oil-paper insulation with different ageing condition}

1. Ageing 0 day

\begin{tabular}{l|l|l|l|l}
\hline Branches & $\tau_{\mathrm{i}}(\mathrm{s})$ & $\mathrm{A}_{\mathrm{i}}$ & $\mathrm{R}_{\mathrm{i}}(\Omega)$ & $\mathrm{C}_{\mathrm{i}}(\mathrm{F})$ \\
\hline 1 & 0.562 & $5.94 \times 10^{-9}$ & $3.36 \times 10^{10}$ & $1.67 \times 10^{-11}$ \\
2 & 1.78 & $1.41 \times 10^{-9}$ & $1.41 \mathrm{E} \times 10^{11}$ & $1.26 \times 10^{-11}$ \\
3 & 5.62 & $4.56 \times 10^{-10}$ & $4.39 \mathrm{E} \times 10^{11}$ & $1.28 \times 10^{-11}$ \\
4 & 17.8 & $1.17 \times 10^{-10}$ & $1.71 \times 10^{12}$ & $1.04 \times 10^{-11}$ \\
5 & 56.2 & $4.35 \times 10^{-11}$ & $4.6 \times 10^{12}$ & $1.22 \times 10^{-11}$ \\
6 & 178 & $1.67 \times 10^{-11}$ & $1.2 \times 10^{13}$ & $1.49 \times 10^{-11}$ \\
7 & 562 & $1.72 \times 10^{-11}$ & $1.16 \times 10^{13}$ & $4.84 \times 10^{-11}$ \\
8 & 1780 & $6.20 \times 10^{-13}$ & $3.03 \times 10^{14}$ & $5.87 \times 10^{-12}$ \\
9 & 5620 & $8.14 \times 10^{-12}$ & $1.45 \times 10^{13}$ & $3.88 \times 10^{-10}$ \\
\hline
\end{tabular}

2. Ageing 30 days

\begin{tabular}{c|l|l|l|l}
\hline Branches & $\tau_{\mathrm{i}}(\mathrm{s})$ & $\mathrm{A}_{\mathrm{i}}$ & $\mathrm{R}_{\mathrm{i}}(\Omega)$ & $\mathrm{C}_{\mathrm{i}}(\mathrm{F})$ \\
\hline 1 & 0.562 & $2.358 \times 10^{-9}$ & $8.48 \times 10^{-10}$ & $6.63 \times 10^{-12}$ \\
2 & 1.78 & $6.053 \times 10^{-10}$ & $3.3 \times 10^{-11}$ & $5.39 \times 10^{-12}$ \\
3 & 5.62 & $1.894 \times 10^{-10}$ & $1.06 \times 10^{-12}$ & $5.32 \times 10^{-12}$ \\
4 & 17.8 & $1.084 \times 10^{-10}$ & $1.85 \times 10^{-12}$ & $9.65 \times 10^{-12}$ \\
5 & 56.2 & $3.451 \times 10^{-11}$ & $5.8 \times 10^{-12}$ & $9.7 \times 10^{-12}$ \\
6 & 178 & $3.403 \times 10^{-11}$ & $5.88 \times 10^{-12}$ & $3.03 \times 10^{-11}$ \\
7 & 562 & $3.615 \times 10^{-12}$ & $5.53 \times 10^{-13}$ & $1.02 \times 10^{-11}$ \\
8 & 1780 & $1.748 \times 10^{-11}$ & $1.08 \times 10^{-13}$ & $1.66 \times 10^{-10}$ \\
9 & 5620 & $7.374 \times 10^{-12}$ & $1.6 \times 10^{-13}$ & $3.52 \times 10^{-10}$ \\
\hline
\end{tabular}

3. Ageing 58 days

\begin{tabular}{l|l|l|l|l}
\hline Branches & $\tau_{\mathrm{i}}(\mathrm{s})$ & $\mathrm{A}_{\mathrm{i}}$ & $\mathrm{R}_{\mathrm{i}}(\Omega)$ & $\mathrm{C}_{\mathrm{i}}(\mathrm{F})$ \\
\hline 1 & 0.562 & $3.67 \times 10^{-9}$ & $5.44 \times 10^{10}$ & $1.03 \times 10^{-11}$ \\
2 & 1.78 & $7.25 \times 10^{-10}$ & $2.76 \times 10^{11}$ & $6.44 \times 10^{-12}$ \\
3 & 5.62 & $3.24 \times 10^{-10}$ & $6.18 \times 10^{11}$ & $9.10 \times 10^{-12}$ \\
4 & 17.8 & $1.13 \times 10^{-10}$ & $1.78 \times 10^{12}$ & $1.00 \times 10^{-11}$ \\
5 & 56.2 & $9.32 \times 10^{-11}$ & $2.15 \times 10^{12}$ & $2.62 \times 10^{-11}$ \\
6 & 178 & $3.37 \times 10^{-11}$ & $5.93 \times 10^{12}$ & $3.00 \times 10^{-11}$ \\
7 & 562 & $5.34 \times 10^{-11}$ & $3.74 \times 10^{12}$ & $1.50 \times 10^{-10}$ \\
8 & 1780 & $7.25 \times 10^{-12}$ & $2.59 \times 10^{13}$ & $6.86 \times 10^{-11}$ \\
9 & 5620 & $1.57 \times 10^{-11}$ & $7.48 \times 10^{12}$ & $7.51 \times 10^{-10}$ \\
\hline
\end{tabular}

4. Ageing 93 days

\begin{tabular}{l|l|l|l|l}
\hline Branches & $\tau_{\mathrm{i}}(\mathrm{s})$ & $\mathrm{A}_{\mathrm{i}}$ & $\mathrm{R}_{\mathrm{i}}(\Omega)$ & $\mathrm{C}_{\mathrm{i}}(\mathrm{F})$ \\
\hline 1 & 0.562 & $2.05 \times 10^{-9}$ & $9.74 \times 10^{10}$ & $5.77 \times 10^{-12}$ \\
2 & 1.78 & $7.97 \times 10^{-10}$ & $2.51 \times 10^{11}$ & $7.09 \times 10^{-12}$ \\
3 & 5.62 & $4.28 \times 10^{-10}$ & $4.67 \times 10^{11}$ & $1.20 \times 10^{-11}$ \\
4 & 17.8 & $1.25 \times 10^{-10}$ & $1.60 \times 10^{12}$ & $1.11 \times 10^{-11}$ \\
5 & 56.2 & $1.70 \times 10^{-10}$ & $1.18 \times 10^{12}$ & $4.77 \times 10^{-11}$ \\
6 & 178 & $9.75 \times 10^{-11}$ & $2.05 \times 10^{12}$ & $8.67 \times 10^{-11}$ \\
7 & 562 & $7.95 \times 10^{-11}$ & $2.52 \times 10^{12}$ & $2.23 \times 10^{-10}$ \\
8 & 1780 & $1.47 \times 10^{-11}$ & $1.28 \times 10^{13}$ & $1.39 \times 10^{-10}$ \\
9 & 5620 & $1.46 \times 10^{-11}$ & $8.09 \times 10^{12}$ & $6.95 \times 10^{-10}$ \\
\hline
\end{tabular}


5. Ageing 120 days

\begin{tabular}{l|l|l|l|l}
\hline Branches & $\tau_{\mathrm{i}}(\mathrm{s})$ & $\mathrm{A}_{\mathrm{i}}$ & $\mathrm{R}_{\mathrm{i}}(\Omega)$ & $\mathrm{C}_{\mathrm{i}}(\mathrm{F})$ \\
\hline 1 & 0.562 & $4.47 \times 10^{-9}$ & $4.48 \times 10^{10}$ & $1.26 \times 10^{-11}$ \\
2 & 1.78 & $1.05 \times 10^{-9}$ & $1.90 \times 10^{11}$ & $9.35 \times 10^{-12}$ \\
3 & 5.62 & $3.75 \times 10^{-10}$ & $5.34 \times 10^{11}$ & $1.05 \times 10^{-11}$ \\
4 & 17.8 & $2.54 \times 10^{-10}$ & $7.89 \times 10^{11}$ & $2.25 \times 10^{-11}$ \\
5 & 56.2 & $2.29 \times 10^{-10}$ & $8.74 \times 10^{11}$ & $6.43 \times 10^{-11}$ \\
6 & 178 & $2.48 \times 10^{-10}$ & $8.07 \times 10^{11}$ & $2.20 \times 10^{-10}$ \\
7 & 562 & $8.50 \times 10^{-11}$ & $2.35 \times 10^{12}$ & $2.39 \times 10^{-10}$ \\
8 & 1780 & $1.36 \times 10^{-11}$ & $1.38 \times 10^{13}$ & $1.29 \times 10^{-10}$ \\
9 & 5620 & $1.57 \times 10^{-11}$ & $7.52 \times 10^{12}$ & $7.48 \times 10^{-10}$ \\
\hline
\end{tabular}

\section{Appendix B: R-C equivalent circuit parameters for natural ester-paper insulation with different ageing condition}

1. Ageing 0 day

\begin{tabular}{l|l|l|l|l}
\hline Branches & $\tau_{\mathrm{i}}(\mathrm{s})$ & $\mathrm{A}_{\mathrm{i}}$ & $\mathrm{R}_{\mathrm{i}}(\Omega)$ & $\mathrm{C}_{\mathrm{i}}(\mathrm{F})$ \\
\hline 1 & 0.562 & $7.15 \times 10^{-9}$ & $2.80 \times 10^{10}$ & $2.01 \times 10^{-11}$ \\
2 & 1.78 & $3.51 \times 10^{-9}$ & $5.69 \times 10^{10}$ & $3.01 \times 10^{-11}$ \\
3 & 5.62 & $1.12 \times 10^{-9}$ & $1.78 \times 10^{11}$ & $3.16 \times 10^{-11}$ \\
4 & 17.8 & $3.81 \times 10^{-10}$ & $5.25 \times 10^{11}$ & $3.38 \times 10^{-11}$ \\
5 & 56.2 & $1.05 \times 10^{-10}$ & $1.91 \times 10^{12}$ & $2.94 \times 10^{-11}$ \\
6 & 178 & $6.64 \times 10^{-11}$ & $3.01 \times 10^{12}$ & $5.90 \times 10^{-11}$ \\
7 & 562 & $2.18 \times 10^{-11}$ & $9.19 \times 10^{12}$ & $6.12 \times 10^{-11}$ \\
8 & 1780 & $2.46 \times 10^{-11}$ & $8.14 \times 10^{12}$ & $2.28 \times 10^{-10}$ \\
9 & 5620 & $2.29 \times 10^{-11}$ & $8.74 \times 10^{12}$ & $6.44 \times 10^{-10}$ \\
\hline
\end{tabular}

2. Ageing 30 day

\begin{tabular}{l|l|l|c|c}
\hline Branches & $\tau_{\mathrm{i}}(\mathrm{s})$ & $\mathrm{A}_{\mathrm{i}}$ & $\mathrm{R}_{\mathrm{i}}(\Omega)$ & $\mathrm{C}_{\mathrm{i}}(\mathrm{F})$ \\
\hline 1 & 0.562 & $6.29 \times 10^{-9}$ & $3.18 \times 10^{10}$ & $1.77 \times 10^{-11}$ \\
2 & 1.78 & $4.26 \times 10^{-9}$ & $4.70 \times 10^{10}$ & $3.79 \times 10^{-11}$ \\
3 & 5.62 & $2.22 \times 10^{-9}$ & $9.02 \times 10^{10}$ & $6.23 \times 10^{-11}$ \\
4 & 17.8 & $6.73 \times 10^{-10}$ & $2.97 \times 10^{11}$ & $5.99 \times 10^{-11}$ \\
5 & 56.2 & $3.62 \times 10^{-10}$ & $5.53 \times 10^{11}$ & $1.02 \times 10^{-10}$ \\
6 & 178 & $6.42 \times 10^{-11}$ & $3.11 \times 10^{12}$ & $5.72 \times 10^{-11}$ \\
7 & 562 & $8.23 \times 10^{-11}$ & $2.43 \times 10^{12}$ & $2.31 \times 10^{-10}$ \\
8 & 1780 & $2.59 \times 10^{-12}$ & $7.26 \times 10^{13}$ & $2.45 \times 10^{-11}$ \\
9 & 5620 & $2.57 \times 10^{-11}$ & $4.58 \times 10^{12}$ & $1.23 \times 10^{-9}$ \\
\hline
\end{tabular}

3. Ageing 58 days

\begin{tabular}{l|l|l|l|l}
\hline Branches & $\tau_{\mathrm{i}}(\mathrm{s})$ & $\mathrm{A}_{\mathrm{i}}$ & $\mathrm{R}_{\mathrm{i}}(\Omega)$ & $\mathrm{C}_{\mathrm{i}}(\mathrm{F})$ \\
\hline 1 & 0.562 & $8.10 \times 10^{-9}$ & $2.47 \times 10^{10}$ & $2.28 \times 10^{-11}$ \\
2 & 1.00 & $3.43 \times 10^{-10}$ & $5.82 \times 10^{11}$ & $1.72 \times 10^{-12}$ \\
3 & 1.78 & $5.89 \times 10^{-9}$ & $3.40 \times 10^{10}$ & $5.24 \times 10^{-11}$ \\
4 & 5.62 & $2.98 \times 10^{-9}$ & $6.71 \times 10^{10}$ & $8.38 \times 10^{-11}$ \\
5 & 17.8 & $1.01 \times 10^{-9}$ & $1.97 \times 10^{11}$ & $9.00 \times 10^{-11}$ \\
6 & 56.2 & $3.83 \times 10^{-10}$ & $5.22 \times 10^{11}$ & $1.08 \times 10^{-10}$ \\
7 & 178 & $2.38 \times 10^{-10}$ & $8.39 \times 10^{11}$ & $2.12 \times 10^{-10}$ \\
8 & 562 & $1.15 \times 10^{-10}$ & $1.75 \times 10^{-12}$ & $3.22 \times 10^{-10}$ \\
9 & 5620 & $3.16 \times 10^{-11}$ & $3.73 \times 10^{12}$ & $1.51 \times 10^{-9}$ \\
\hline
\end{tabular}

4. Ageing 93 days

\begin{tabular}{l|l|l|l|l}
\hline Branches & $\tau_{\mathrm{i}}(\mathrm{s})$ & $\mathrm{A}_{\mathrm{i}}$ & $\mathrm{R}_{\mathrm{i}}(\Omega)$ & $\mathrm{C}_{\mathrm{i}}(\mathrm{F})$ \\
\hline 1 & 0.562 & $5.80 \times 10^{-9}$ & $3.18 \times 10^{10}$ & $1.77 \times 10^{-11}$ \\
2 & 1.78 & $9.38 \times 10^{-9}$ & $4.70 \times 10^{10}$ & $3.79 \times 10^{-11}$ \\
3 & 5.62 & $3.34 \times 10^{-9}$ & $9.02 \times 10^{10}$ & $6.23 \times 10^{-11}$ \\
4 & 17.8 & $1.36 \times 10^{-9}$ & $2.97 \times 10^{11}$ & $5.99 \times 10^{-11}$ \\
5 & 56.2 & $3.59 \times 10^{-10}$ & $5.53 \times 10^{11}$ & $1.02 \times 10^{-10}$ \\
6 & 178 & $3.34 \times 10^{-10}$ & $3.11 \times 10^{12}$ & $5.72 \times 10^{-11}$ \\
7 & 562 & $1.18 \times 10^{-10}$ & $2.43 \times 10^{12}$ & $2.31 \times 10^{-10}$ \\
8 & 1780 & $3.36 \times 10^{-11}$ & $7.26 \times 10^{13}$ & $2.45 \times 10^{-11}$ \\
9 & 5620 & $2.65 \times 10^{-11}$ & $4.58 \times 10^{12}$ & $1.23 \times 10^{-9}$ \\
\hline
\end{tabular}

5. Ageing 120 days

\begin{tabular}{l|l|l|l|l}
\hline Branches & $\tau_{\mathrm{i}}(\mathrm{s})$ & $\mathrm{A}_{\mathrm{i}}$ & $\mathrm{R}_{\mathrm{i}}(\Omega)$ & $\mathrm{C}_{\mathrm{i}}(\mathrm{F})$ \\
\hline 1 & 0.562 & $2.73 \times 10^{-8}$ & $7.33 \times 10^{9}$ & $7.67 \times 10^{-11}$ \\
2 & 1.78 & $7.37 \times 10^{-9}$ & $2.71 \times 10^{10}$ & $6.56 \times 10^{-11}$ \\
3 & 5.62 & $2.95 \times 10^{-9}$ & $6.78 \times 10^{10}$ & $8.29 \times 10^{-11}$ \\
4 & 17.8 & $1.01 \times 10^{-9}$ & $1.98 \times 10^{11}$ & $8.99 \times 10^{-11}$ \\
5 & 56.2 & $6.32 \times 10^{-10}$ & $3.16 \times 10^{11}$ & $1.78 \times 10^{-10}$ \\
6 & 178 & $3.13 \times 10^{-10}$ & $6.39 \times 10^{11}$ & $2.79 \times 10^{-10}$ \\
7 & 562 & $1.49 \times 10^{-10}$ & $1.34 \times 10^{12}$ & $4.19 \times 10^{-10}$ \\
8 & 1780 & $1.04 \times 10^{-11}$ & $1.81 \times 10^{13}$ & $9.85 \times 10^{-11}$ \\
9 & 5620 & $5.32 \times 10^{-11}$ & $2.22 \times 10^{12}$ & $2.54 \times 10^{-9}$ \\
\hline
\end{tabular}

\section{REFERENCES}

[1] M. Emsley and G. C. Stevens, "Kinetics and mechanisms of the low temperature degradation of cellulose", Cellulose, Vol. 1, No. 1, pp. 26-56, 1994

[2] R. Liao, S. Liang, C. Sun, L. Yang and H. Sun, "A comparative study of thermal aging of transformer insulation paper impregnated in natural ester and in mineral oil", European Trans. Electr. Power, Vol. 20, pp. 518-533, 2010.

[3] D. Woodcock, "Risk-Based Reinvestment-Trends in Upgrading the Aged T\&D System".

http://www.energypulse.net/centers/article/article_display.cfm?a_id=63.

[4] R. Fournié, "Les isolants en électrotechnique: Essais, Mécanismes de dégradation, Applications industrielles", Collection de la Direction des Études et Recherches d'électricité de France, Eyrolles, Paris, France, 1990.

[5] T. K. Saha, "Review of modern diagnostic techniques for assessing insulation condition in aged transformers", IEEE Trans. Dielectr. Electr. Insul. Vol. 10, pp. 903-917, 2003.

[6] M. de Nigris, R. Passaglia, R. Berti, L. Bergonzi and R. Maggi, "Application of modern techniques for the condition assessment of power transformers", CIGRE Session 2004, Paris, France, Paper A2-207, 2004.

[7] A. Seytashmehr, I. Fofana, C. Eichler, A. Akbari, H. Borsi and E. Gockenbach, "Dielectric spectroscopic measurements on transformer oil-paper insulation under controlled laboratory conditions", IEEE Trans. Dielectr. Electr. Insul., Vol. 15, No. 4, pp. 1100-1111, 2008.

[8] W. S. Zaengl, "Dielectric spectroscopy in time and frequency domain for HV power equipment, Part I: Theoretical considerations", IEEE Electr. Insul. Mag., Vol. 19, No. 5, pp. 5-19, 2003.

[9] W. S. Zaengl, "Application of dielectric spectroscopy in time and frequency domain for HV power equipment", IEEE Electr. Insul. Mag., Vol. 19, No. 6, pp. 9-22, 2003.

[10] A. Seytashmehr, I. Fofana, A. Akbari, H. Borsi and E. Gockenbach, "Effects of temperature on the dielectric response of transformer insulation", 15th International Symposium on High-Voltage Engineering, ISH 2007, Ljubljana, Slovenia, paper T8-537, 2007

[11] I. Fofana, I. Hemmatjou, H. Farzaneh, M. Gockenbach and H. Borsi, "Polarization and Depolarization Current measurements of oil impregnated paper insulation system under thermal runaway", IEEE Int'l. Conf. Solid Dielectrics (ICSD), pp.1-4, 2010. 
[12] T. K. Saha and P. Purkait, "Understanding the impacts of moisture and thermal ageing on transformer's insulation by dielectric response and molecular weight measurements", IEEE Trans. Dielectr. Electr. Insul., Vol.15, No. 2, pp. 568-582, 2008.

[13] S. Wang, G. Zhang, J. Wei, S. Yang, M. Dong and X. Huang, "Investigation on dielectric response characteristics of thermally aged insulating pressboard in vacuum and oil-impregnated ambient", IEEE Trans. Dielectr. Electr. Insul., Vol.17, No. 16, pp.1853-1862, 2010.

[14] T. Leibfried, A. J. Kachler, W. S. Zaengl, V. Der Houhanessian, A. Küchler and B. Breitenbauch, "Ageing and moisture analysis of power transformer insulation systems", CIGRE 2002, Paper 12 101, 2002.

[15] T. K. Saha and P. Purkait, "Investigating the impacts of ageing and moisture on dielectric response of oil/paper insulation systems", Int'l. Sympos. High Voltage Eng. (ISH), Delft, Netherlands, pp.1-4, 2003.

[16] D. Martin, I. Khan, J. Dai and Z. D. Wang, "An overview of the suitability of vegetable oil dielectrics for use in large power transformers", TJH2b Euro Tech. Conf., Chester, UK, pp.1-20, 2006.

[17] D. Martin, Z. D. Wang, P. Dyer, A. W. Darwin and I. R. James, "A comparative study of the dielectric strength of ester impregnated cellulose for use in large power transformers", IEEE Int'l. Conf. Solid Dielectr. (ICSD), Winchester, UK, pp. 294-297, 2007.

[18] C. P. McShane, "Vegetable oil based dielectric coolants", IEEE Industry Applications Mag., Vol. 8, No. 2, pp. 34-41, 2002.

[19] T. V. Oommen, "Vegetable oils for liquid filled transformers", IEEE Electr. Insul. Mag., Vol. 18, No. 1, pp. 6-11. 2002.

[20] N. A. Muhamad, B. T. Phung T. R. Blackburn and K. X Lai, "Polarization and Depolarization Current (PDC) tests on biodegradable and mineral transformer oils at different moisture levels", Australasian Universities Power Engineering Conf., pp.1-6, 2009

[21] T. K. Saha, P. Purkait and F. Muller, "Deriving equivalent circuit of transformers insulation for ynderstanding the dielectric response measurements", IEEE Trans. Power Delivery, Vol. 20, pp. 149-157, 2005.

[22] T. Leibfried and A. J. Kachler, "Insulation diagnostics on power transformers using the polarisation and depolarisation current (PDC) Analysis", IEEE Int'l. Sympos. Electr. Insul. (ISEI), pp. 170-173, 2002.

[23] H. A. P. Silva, W. Bassi and A. C. T. Diogo, "Non-invasive ageing assessment by means of polarization and depolarization currents analysis and its correlation with moisture content for power transformer life management", IEEE/PES Transmission \& Distribution Conf. \& Exposition, Latin, America, pp. 611-616, 2004.

[24] I. Fofana, V. Wasserberg, H. Borsi and E. Gockenbach, "Challenge for a mixed insulating liquid for using in high voltage transformers. Part 1: Investigation of mixed liquids", IEEE Electr. Insul. Mag., Vol. 18, No. 3, pp. 18-31, 2002.

[25] Suwarno and I. S. Darma, "Dielectric properties of mixtures between mineral oil and natural ester from palm oil", World Scientific and Engineering Academy and Society (WSEAS) Trans. on Power Systems, Vol. 3, No. 2, pp. 37-46, 2008.

[26] T. K. Saha, M. K. Pradhan, and J. H. Yew, "Optimal time selection for the polarisation and depolarisation current measurement for power transformer insulation diagnosis", IEEE Power Engineering Soc. General Meeting, Tampa, FL, USA, pp. 1-7, 2007.

[27] PDC-ANALYSER-1MOD User's Guide, Alff Engineering, Switzerland, 2000.

[28] I. Fofanaa, H. Hemmatjoua and M. Farzaneh, "Low temperature and moisture effects on polarization and depolarization currents of oil-paper insulation", Electric Power Systems Research, Vol. 80, pp. 91-97, 2010.

[29] T. V. Oommen, "Moisture equilibrium charts for transformer insulation drying practice", IEEE Trans. Power App. Syst., Vol. 103, pp. 3063$3067,1984$.

[30] K. J. Rapp, C. P. McShane and J. Luksich, "Interaction mechanisms of natural ester dielectric fluid and Kraft paper", IEEE Int'l. Conf. Dielectr. Liquids (ICDL), Portugal, pp. 393-396, 2005.

[31] C. P. McShane, K. J. Rapp, J. L. Corkran, G. A. Gauger and J. Luksich, "Ageing of paper insulation in natural ester dielectric fluid", IEEE/PES Transmission \& Distribution Conf. \& Exposition, Atlanta GA, USA, Vol. 2, pp. 675-679, 2001.

[32] T. Leibfried and A. J. Kachler, "Insulation diagnostics on power transformers using the polarisation and depolarisation current (PDC) Analysis", IEEE Int'l. Sympos. Electr. Insul. (ISEI), pp. 170-173, 2002.

[33] T. K. Saha and P. Purkait, "Investigating Some Important Parameters of the PDC Measurement Technique for the Insulation Condition
Assessment of Power Transformer", 6th Int'l. Power Eng. Conf., Singapore, pp. 381-386, 2003.

[34] T. K. Saha and P. Purkait, "Effects of temperature on time-domain dielectric diagnostics of transformers", Australasian Universities Power Engineering Conf., Christchurch, New Zealand, pp. 1-7, 2003.

[35] T. K. Saha and P. Purkait, "Investigation of polarization and depolarization current measurements for the assessment of oil-paper insulation of aged transformers", IEEE Trans. Dielectr. Electr. Insul., Vol. 11, No. 1, pp. 144-154, 2004.

[36] I. Fofana, H. Hemmatjou and F. Meghnefi, "Effect of thermal transient on the polarization and depolarization current measurements of oil-paper insulation", IEEE Trans. Dielectr. Electr. Insul., Vol. 18, No. 2, pp. 513$520,2011$.

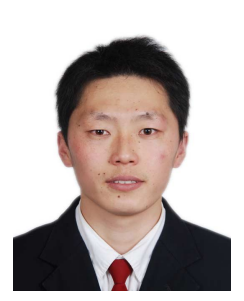

Jian Hao was born in Hebei, China in 1984. He received the B.Eng. and B.Econ. degrees (2007) from the College of Electrical Engineering and College of Economics and Business Administration, Chongqing University, China. Now, he is a Ph.D. candidate in the College of Electrical Engineering, Chongqing University, China. His research activities are mainly in the field dielectric response of oil-paper insulation system for high voltage apparatus.

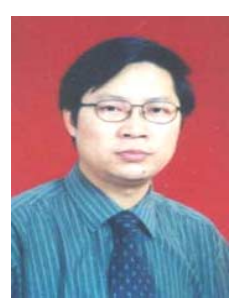

Ruijin Liao was born in Sichuan, China in 1963. He received the M.S. and Ph.D. degrees in electrical engineering from Xi'an Jiaotong University, China and Chongqing University, China, respectively. Since 1999 he is a professor of Electrical Engineering College at Chongqing University, China. His research activities lie in the field of on-line monitoring of insulation condition and fault diagnosis for high voltage apparatus, as well as ageing mechanism and diagnosis for power transformer. He is author/ coauthor of one book and over 90 journal and international conferences.

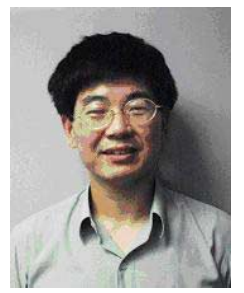

George Chen was born in China in 1961. He received the B.Eng. (1983) and M.Sc. (1986) degrees in electrical engineering from Xi'an Jiaotong University, China. He obtained the Ph.D. degree (1990) from the University of Strathclyde, UK, on permanent changes in electrical properties of irradiated low-density polyethylene. He joined the University of Southampton as postdoctoral research fellow and became a senior research fellow subsequently. In 1997 he was appointed as a research lecturer and promoted to a Reader in 2002. Over the years, he has developed a wide range of interests in high voltage engineering and electrical properties of materials and published over 200 papers.

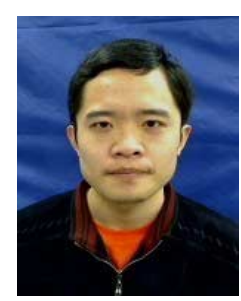

Zhiqin Ma was born in Henan, China in 1986. He received the B.Eng. degree (2009) in electrical engineering from Chongqing University, China. His major research interests include online detection of insulation condition of electrical devices, and insulation fault diagnosis for high voltage equipment.

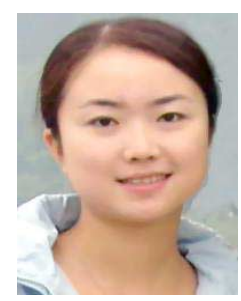

Lijun Yang was born in Sichuan, China in 1980. She received her M.S. and Ph.D. degrees in electrical engineering from Chongqing University, China in 2004 and 2009. Her major research interests include online detection of insulation condition of electrical devices, partial discharges, and insulation fault diagnosis for high voltage equipment. 